\title{
TTR
}

Traduction, terminologie, re?daction

\section{In memoriam Daniel Simeoni}

\section{Annick Chapdelaine}

Volume 19, numéro 2, 2e semestre 2006

Traduire les Amériques

Translating the Americas

URI : https://id.erudit.org/iderudit/017820ar

DOI : https://doi.org/10.7202/017820ar

Aller au sommaire du numéro

\section{Éditeur(s)}

Association canadienne de traductologie

ISSN

0835-8443 (imprimé)

1708-2188 (numérique)

Découvrir la revue

\section{Citer ce document}

Chapdelaine, A. (2006). In memoriam Daniel Simeoni. TTR, 19(2), 9-9.

https://doi.org/10.7202/017820ar

Tous droits réservés (c) TTR: traduction, terminologie, rédaction Les auteurs, 2008
Ce document est protégé par la loi sur le droit d'auteur. L’utilisation des services d'Érudit (y compris la reproduction) est assujettie à sa politique d'utilisation que vous pouvez consulter en ligne.

https://apropos.erudit.org/fr/usagers/politique-dutilisation/ 


\section{In memoriam Daniel Simeoni}

Au moment de mettre sous presse, nous apprenons la disparition de Daniel Simeoni. La revue TTR est en deuil d'un penseur et d'un proche collaborateur. En effet, TTR doit beaucoup au traductologue généreux qu'il fut. Membre du comité de rédaction depuis le volume XII en 1999, il a été l'homme de tous les temps et de tous les numéros, toujours prêt à partager ses connaissances, ses lectures et ses vues sur la recherche en traduction. Par son universalisme, son humanisme et son érudition, il aura laissé son empreinte sur la revue. Évaluateur d'articles aux commentaires riches et constructifs, penseur profond, collaborateur à l'humour sagace, il nous manquera beaucoup.

Au nom du comité de rédaction et des collaboratrices à l'édition, je tiens à exprimer nos plus sincères condoléances à sa famille et à ses proches.

Annick Chapdelaine

Directrice de TTR 